
- badania $w$ gminie Stubice

$\mathrm{W}$ YBORY SAMORZĄDOWE BUDZĄ CORAZ WIĘKSZE ZAINTERESOWANIE WŚRÓD Polaków ${ }^{1}$. Zaczynają oni dostrzegać bezpośrednie przełożenie swoich decyzji wyborczych na jakość życia (Cybulska, 2014, s. 1). W końcu to w kompetencjach władz samorządowych leżą kwestie, z którymi obywatele zmagają się na co dzień - szkoły, chodniki, ścieżki rowerowe, gospodarka komunalna, wysypiska śmieci, tereny zielone itp. (ustawa o samorządzie gminnym, 1990, art.7 ust. 1). Dostrzegając wzrost zainteresowania tymi wyborami, studenci Wydziału Nauk Politycznych i Dziennikarstwa Uniwersytetu im. Adama Mickiewicz postanowili właśnie w okresie kampanii wyborczej do organów władz samorządowych w 2014 r. przeprowadzić badania w ramach projektu naukowego pt. Personalizacja polityki na poziomie lokalnym.

Personalizacja polityki oznacza „postrzeganie polityki przez pryzmat osób, nie procesów, oraz istotniejszą rolę jednostki niż instytucji” (Piontek, 2012, s. 113). Zakłada się, że wyborcy podejmując decyzje o wyborze kandydata, kierują się w większym stopniu jego cechami osobistymi niż programem wyborczym komitetu, który reprezentuje. Wiążę się z tym przeniesienie akcentów kampanii wyborczej z prezentowania partii politycznej na przedstawianie jednostki. Wybory na stanowisko wójta/burmistrza/prezydenta miasta stanowią więc doskonałą okazję do zbadania tego zjawiska w skali mikro.

Celem projektu była analiza zjawiska personalizacji polityki na poziomie lokalnym, poprzez zbadanie przyczyn uczestnictwa w wyborach samorządowych oraz motywów, jakimi kierują się osoby uprawnione do głosowania przy wyborze kandydata na stanowisko wójta/burmistrza/prezydenta miasta. W ramach projektu postawiono następujące pytania badawcze:

1. Czy mieszkańcy danej gminy mają zamiar uczestniczyć w wyborach samorządowych, które odbędą się 16 listopada 2014 r.?

${ }^{1} \mathrm{Na}$ podstawie badań CBOS (Cybulska, 2014, s. 1) 
2. Jakie są przyczyny uczestnictwa w głosowaniu, a jakie absencji wyborczej?

3. Czym wyborcy kierują się, podejmując decyzje o głosowaniu na konkretnego kandydata?

4. Czy indywidualne cechy wyborców (wiek, płeć, wykształcenie) wpływają na ich decyzje wyborcze?

5. W jaki sposób postąpią wyborcy podczas II tury głosowania, jeśli na liście nie będzie kandydata, na którego głosowali podczas I tury?

Projekt został zrealizowany i zaplanowany przez Koło Naukowe Psychologii Polityki we współpracy z Kołem Naukowym Samorządu Terytorialnego Wydziału Nauk Politycznych i Dziennikarstwa Uniwersytetu im. Adama Mickiewicza. Badania odbyły się w dwóch gminach - Słubice i Gniezno ${ }^{2}$. Niniejszy artykuł przestawia wyniki uzyskane w Słubicach, w których prace badawcze prowadzone były w dniach 21-22.10.2014 r.

W projekcie zastosowano jedną z metod badań ilościowych - metodę badania sondażowego, które zostało zrealizowane techniką PAPI. $\mathrm{Na}$ potrzeby badania skonstruowano kwestionariusz składający się z 10 pytań, z czego 6 miała charakter merytoryczny (pytania związane z zachowaniami wyborczymi), a 4 metryczkowy (płeć, wiek, wykształcenie, miejsce zamieszkania). Pytania miały charakter zamknięty, istniała możliwość zaznaczenia kilku wariantów odpowiedzi, bez nadawania priorytetów. Dobór próby był losowy z uwzględnieniem struktury demograficznej mieszkańców określonej na podstawie danych Głównego Urzędu Statystycznego (Statystyczne Vademecum Samorządowca, 2014, s. 1)33. Badani musieli mieć jednak uprawnienia do głosowania w wyborach samorządowych na terenie gminy Słubice. W ten sposób zebrano 381 ankiet.

W badaniach wzięło udział 177 mężczyzn (46\%) i 204 kobiety (54\%). Wśród respondentów było $12 \%$ osób w wieku 18-25 lat, 13\% w przedziale wiekowym 26-35, 27\% w grupie 36-50 lat, 35\% w gronie 50-65 lat i 13\% osób w wieku 65 plus. Ze względu na wykształcenie

${ }^{2}$ Wyniki badań z Gniezna zostały przedstawione w osobnym raporcie, który został opublikowany w tym samym numerze czasopisma „Refleksje” pt. „Wpływ indywidualnych cech wyborców na ich aktywność polityczną na przykładzie wyborów samorządowych w Gnieźnie w 2014 roku”

${ }^{3} \mathrm{Z}$ dostępnych danych wynikało, że 50\% mieszkańców stanowią kobiety. Ze względu na wiek pojawily się trzy kategorie: osoby w wieku przedprodukcyjnym, produkcyjnym i poprodukcyjnym (18\% mieszkańców). Brak danych dotyczących wykształcenia. 
podzielono osoby odpowiadające na cztery grupy: podstawowe $-8 \%$ osób, zawodowe $-27 \%$ osób, średnie $-45 \%$ osób i wyższe - $20 \%$ osób. Na pytania zawarte w kwestionariuszu odpowiadali częściej mieszkańcy miasta $-88 \%$ osób, niż wsi - $12 \%$ osób.

Na pierwsze podstawowe pytanie: Czy zamierza Pan/Pani głosować w wyborach samorządowych, które będą miały miejsce 16 listopada 2014 roku? 232 osoby (61\%) odpowiedziały tak, 108 nie (28\%), a 41 respondentów (11\%) nie podjęło jeszcze decyzji w tej sprawie i wybrało odpowiedź nie wiem. Kwestionariusz został skonstruowany w taki sposób, że osoby, które zadeklarowały absencję wyborczą, odpowiadały jeszcze tylko na jedno pytanie merytoryczne - dotyczące przyczyn nieuczestniczenia w wyborach. Pozostali respondenci natomiast byli pytani o motywy uczestnictwa w wyborach, preferencje wyborcze, przyczyny wyboru konkretnego kandydata oraz sposób postępowania w II turze wyborów.

W dniu prowadzenia badań zdecydowana większość respondentów podjęła już decyzję związaną z uczestnictwem w wyborach. Niezdecydowanych było tylko 41 osób, z czego 25 osób (14\% badanej grupy) stanowiły kobiety, a 16 (15\% badanej grupy) mężczyźni. Różnice wśród niezdecydowanych uwzględniające wiek bądź wykształcenie również były nieznaczne. Podział respondentów ze względu na indywidualne cechy wyborców uwzględniający odpowiedź na pierwsze pytanie obrazuje poniższa tabela.

Tabela 1 Podział respondentów ze względu na indywidualne cechy wyborców

\begin{tabular}{|l|l|c|c|c|}
\hline \multicolumn{2}{|c|}{$\begin{array}{c}\text { Czy zamierza Pan/Pani } \\
\text { głosować w wyborach } \\
\text { samorządowych? }\end{array}$} & Tak & Nie & Nie wiem \\
\hline \multirow{2}{*}{ Płeć } & Kobieta & 131 & 48 & 25 \\
\cline { 2 - 5 } & Mężczyzna & 101 & 60 & 16 \\
\hline \multirow{4}{*}{ Wiek } & $18-25$ & 28 & 15 & 6 \\
\cline { 2 - 5 } & $26-35$ & 23 & 19 & 7 \\
\cline { 2 - 5 } & $36-50$ & 60 & 29 & 12 \\
\cline { 2 - 5 } & $51-65$ & 84 & 37 & 13 \\
\cline { 2 - 5 } & $65^{+}$ & 37 & 8 & 3 \\
\hline
\end{tabular}




\begin{tabular}{|l|l|c|c|c|}
\hline \multicolumn{2}{|c|}{$\begin{array}{c}\text { Czy zamierza Pan/Pani } \\
\text { głosować w wyborach } \\
\text { samorządowych? }\end{array}$} & Tak & Nie & Nie wiem \\
\hline Wykształcenie & $\begin{array}{l}\text { Podsta- } \\
\text { wowe }\end{array}$ & 16 & 11 & 2 \\
\cline { 2 - 5 } & Zawodowe & 50 & 40 & 13 \\
\cline { 2 - 5 } & Średnie & 107 & 46 & 18 \\
\cline { 2 - 5 } & Wyższe & 59 & 11 & 8 \\
\hline
\end{tabular}

Źródło: opracowanie własne.

\section{ABSENCJA WYBORCZA}

ABSENCJĘ WYBORCZĄ DEKLAROWAŁO ZDECYDOWANIE WIĘCEJ MĘŻCZYZN (34\% spośród badanej grupy) niż kobiet (24\%). Największy procent niegłosujących był wśród osób w wieku 26-35 lat (39\%), najmniejszy natomiast $\mathrm{w}$ grupie $65^{+}(17 \%)$. W przypadku wykształcenia wysoką deklarowaną absencje odnotowano w grupie osób z wykształceniem zawodowym (39\%) i podstawowym (38\%), najniższą natomiast w grupie osób z wykształceniem wyższym (14\%). Jednocześnie ogólna deklarowana absencja ukształtowała się na poziomie $28 \%$.

Respondenci, którzy stwierdzili, że nie mają zamiaru uczestniczyć w wyborach, byli następnie pytani o przyczyny takiego postępowania. Mogli wybrać odpowiedź spośród pięciu wskazanych w pytaniu: (1) nigdy nie głosuję, (2) nie interesuje mnie polityka, (3) uważam, że to strata czasu, (4) mam dość zachowania polityków, którzy dużo obiecują i nic nie robią, (5) nie chcę brać na siebie odpowiedzialności. Respondenci mogli wskazać więcej niż jedną przyczynę. Najczęściej wybieraną opcją było „mam dość zachowania polityków, którzy dużo obiecują i nic nie robią", którą wskazano aż 60 razy. Najrzadziej decydowano się na odpowiedź „nie chcę brać na siebie odpowiedzialności”. Zdecydowało się na nią tylko 8 osób. Częstotliwość wyboru poszczególnych przyczyn obrazuje poniższy wykres: 
Wykres 1 Przyczyny absencji wyborczej

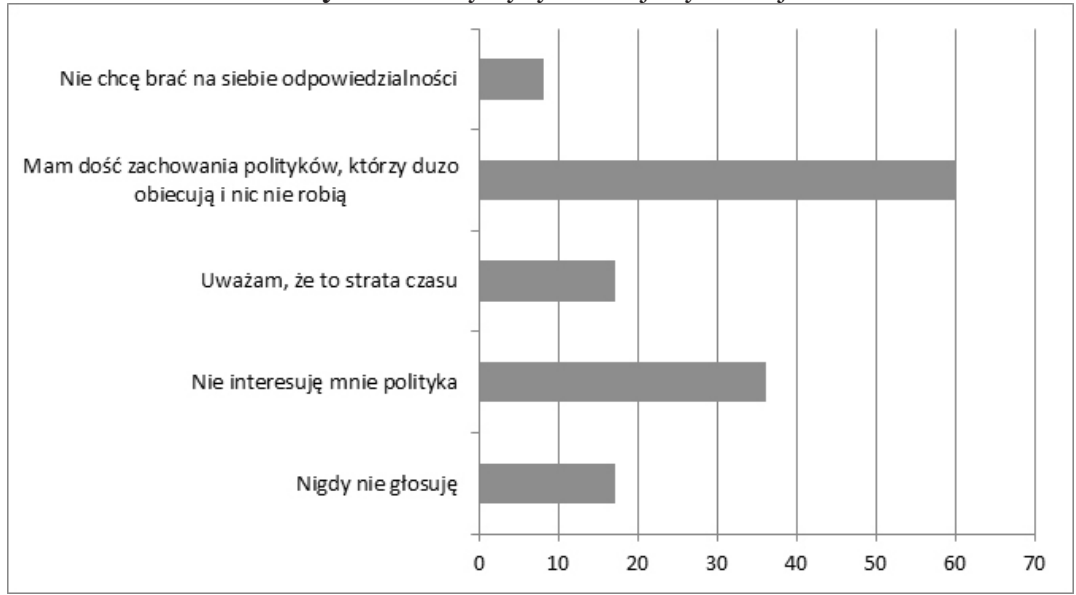

Źródło: opracowanie własne

Zarówno kobiety, jak i mężczyźni najczęściej jako przyczynę absencji podawali rozczarowanie zachowaniem polityków. W przypadku obu płci kolejnym z powodów był brak zainteresowania polityką. Różnica pojawia się dopiero w przypadku trzeciej w kolejności motywacji - mężczyźni wskazywali na stratę czasu, kobiety natomiast na fakt, że nigdy nie uczestniczą w wyborach. Dokładny rozkład odpowiedzi uwzględniający indywidualne cechy wyborców obrazuje tabela 2.

Zdecydowanie mniej jednomyślnie rozkładają się deklaracje badanych na temat przyczyny planowanej absencji wyborczej, jeśli uwzględnimy kategorie wieku. Osoby do 35 roku życia najczęściej wskazywały brak zainteresowani polityką. Respondenci, którzy ukończyli 35 lat jako przyczynę absencji podawali najczęściej rozczarowanie zachowaniem polityków. Niezależnie od wieku respondenci rzadko decydowali się na odpowiedź związaną z poczuciem odpowiedzialności. W kategorii osób powyżej 65 roku życia ani razu nie wskazano jako motywacji do pozostania $\mathrm{w}$ dniu wyborów w domu poczucia zmarnowanego czasu.

W przypadku wykształcenia, niezależnie od jego poziomu, najczęściej wskazywaną odpowiedzią było rozczarowanie zachowaniem polityków. Zróżnicowanie jeśli chodzi o motywacje uwzględniając tę kategorię, pojawia się dopiero przy odpowiedzi "nigdy nie głosuję". Żadna z osób z wykształceniem wyższym nie zdecydowała się na wskazanie tej opcji jako powód absencji. Dokładny rozkład odpowiedzi uwzględniający indywidualne cechy wyborcy obrazuję poniższa tabela nr 2. 


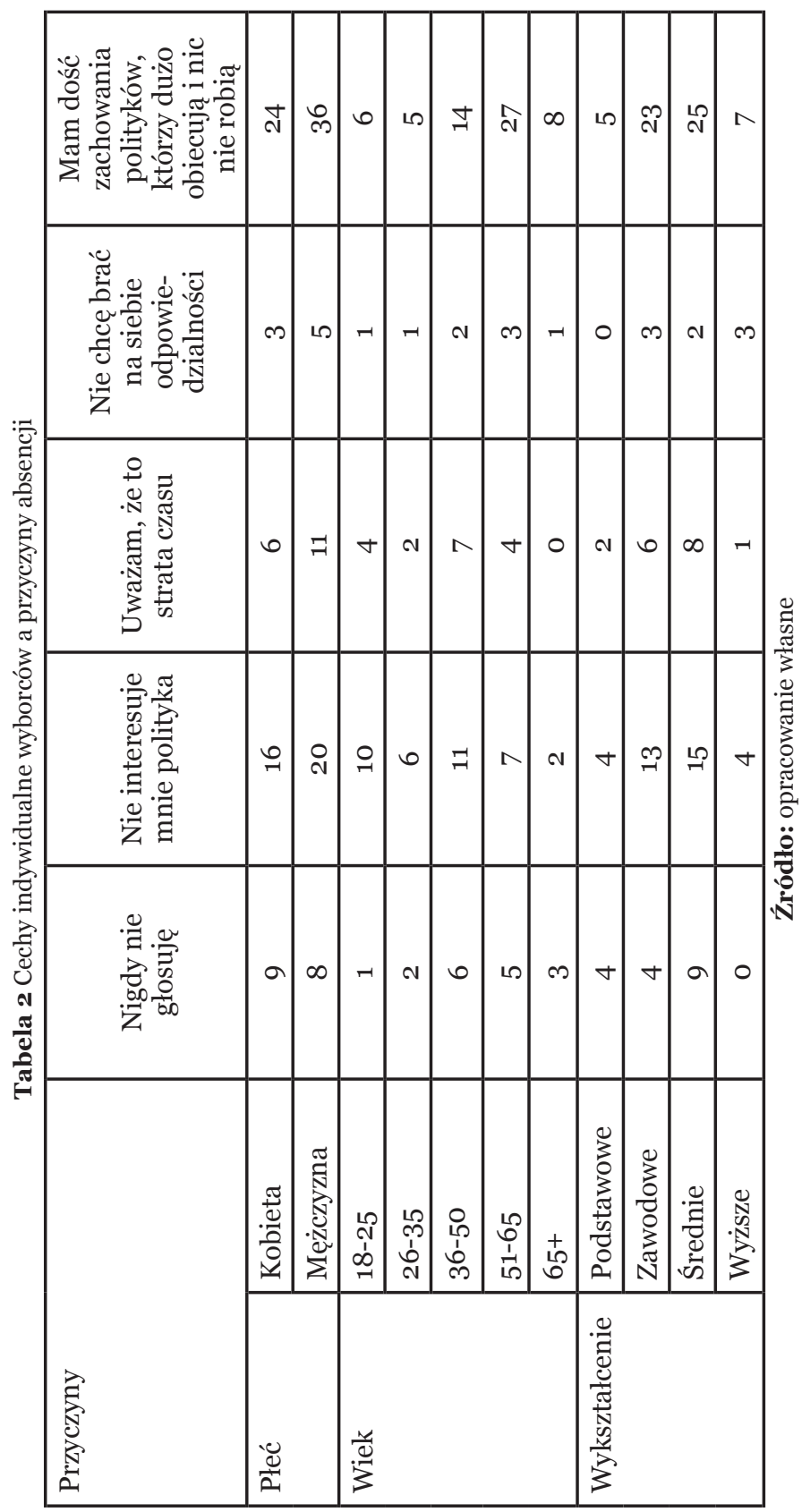




\section{DEKLARACJA UDZIAEU W WYBORACH}

PrZEPROWADZONE w SŁUbiCACH BADANIA WYKAZAŁY, ŻE UdZIAŁ W WYBORACH deklarowało zdecydowanie więcej kobiet (64\% spośród badanej grupy) niż mężczyzn (57\%). Najwięcej głosujących jest wśród osób w wieku $65+(77 \%)$, najmniej natomiast w grupie 26-35 lat (47\%).W przypadku wykształcenia wysokie deklarowane uczestnictwo w wyborach odnotowano w grupie osób z wykształceniem wyższym (76\%), najniższe natomiast w grupie osób z wykształceniem zawodowym (49\%). Jednocześnie ogólna deklarowana frekwencja ukształtowała się na poziomie 61\%. Szczegółowe dane znajdują się w tabeli numer 3.

Osobną kategorię stanowili respondenci niezdecydowani, którzy jednak w kolejnej części ankiety byli proszeni o podanie motywów, które mogłyby ich przekonać do uczestnictwa w wyborach oraz prawdopodobnych przyczyn głosowania na danego kandydata. W dalszej części artykułu wyniki osób niezdecydowanych i deklarujących uczestnictwo w wyborach traktowane są zbiorczo ${ }^{4}$. Respondenci, którzy nie podjęli jeszcze decyzji, czy będą uczestniczyć w wyborach, stanowili 11\% ankietowanych. Częściej niezdecydowane były kobiety (12\%) niż mężczyźni (9\%). Najmniejszy odsetek niezdecydowanych jest wśród osób 65+ (6\%), największy natomiast w grupie wiekowej 26-35 lat (14\%). W przypadku wykształcenia najczęściej kategorie „nie wiem” wskazywały osoby z wykształceniem zawodowym (12\%).

W kwestionariuszu pojawiło się pięć przyczyn uczestnictwa w wyborach: (1) zawsze głosuję, (2) to jest mój obywatelski obowiązek, (3) chcę wziąć sprawy w swoje ręce, (4) mam swojego kandydata i chcę, aby wygrał, (5) oczekuję zmian na lepsze. Respondenci mogli wskazać kilka odpowiedzi. Najczęściej wybieraną opcją była „zawsze głosuję, którą wskazano 122 razy. Najrzadziej wskazywano odpowiedź „chcę wziąć sprawy w swoje ręce”. Zdecydowało się na nią 25 osób. Częstotliwość wyboru poszczególnych przyczyn obrazuje wykres nr 2.

Zarówno mężczyźni, jak i kobiety jako powód uczestnictwa w wyborach najczęściej wskazywali fakt, że „zawsze biorą udział w głosowa-

${ }^{4} \mathrm{~W}$ dalszej części artykułu wyniki osób niezdecydowanych i deklarujących uczestnictwo w wyborach traktowane są zbiorczo ze względu na początkowe założenia przy prowadzeniu badań. Podstawowym celem projektu był sprawdzenie, czy na poziomie lokalnym mamy do czynienia z zjawiskiem personalizacji polityki. By powiększyć próbę zdecydowano na początku badań, że również osoby niezdecydowane będą pytane o ewentualne preferencje i przyczyny głosowania na danego kandydata. W trakcie opracowywania danych okazało się, że nie występują istotne różnice pomiędzy osobami niezdecydowanymi, a deklarującymi uczestnictwo w wyborach zdecydowano się, więc potraktować ich wyniki zbiorczo. 
niu”. U obu płci na drugim miejscu znalazło się poczucie obywatelskiego obowiązku, na trzecim oczekiwanie zmian na lepsze. Najrzadziej wskazywano próbę wzięcia sprawy w swoje ręce. Jest to również jedyna odpowiedź, którą częściej wybierali mężczyźni niż kobiety.

W przypadku kategorii wieku mamy do czynienia ze zdecydowanie większą różnorodnością w rozkładzie głosów ankietowanych. Osoby powyżej 35 roku życia najczęściej decydowały się na odpowiedź „zawsze głosuję”. Najmłodsi respondenci wskazywali jako przyczynę posiadanie konkretnego kandydata, na którego chcą oddać głos, a osoby w przedziale wiekowym 26-35 wybierały jako motywację poczucie, że uczestnictwo w wyborach to ich obywatelski obowiązek. Ankietowani między 36 a 50 rokiem życia najrzadziej decydowali się na odpowiedź „chcę wziąć sprawy w swoje ręce”. W grupie 51-65 lat ta opcja również uzyskała najmniejszą liczbę wskazań, na równi ze stwierdzeniem, że przyczyną uczestnictwa w wyborach jest posiadanie swojego kandydata. Tylko jedna osoby $\mathrm{w}$ wieku $65^{+}$oczekiwała w związku z uczestnictwem $\mathrm{w}$ wyborach zmian na lepsze.

Wykres 2 Przyczyny uczestnictwa w wyborów

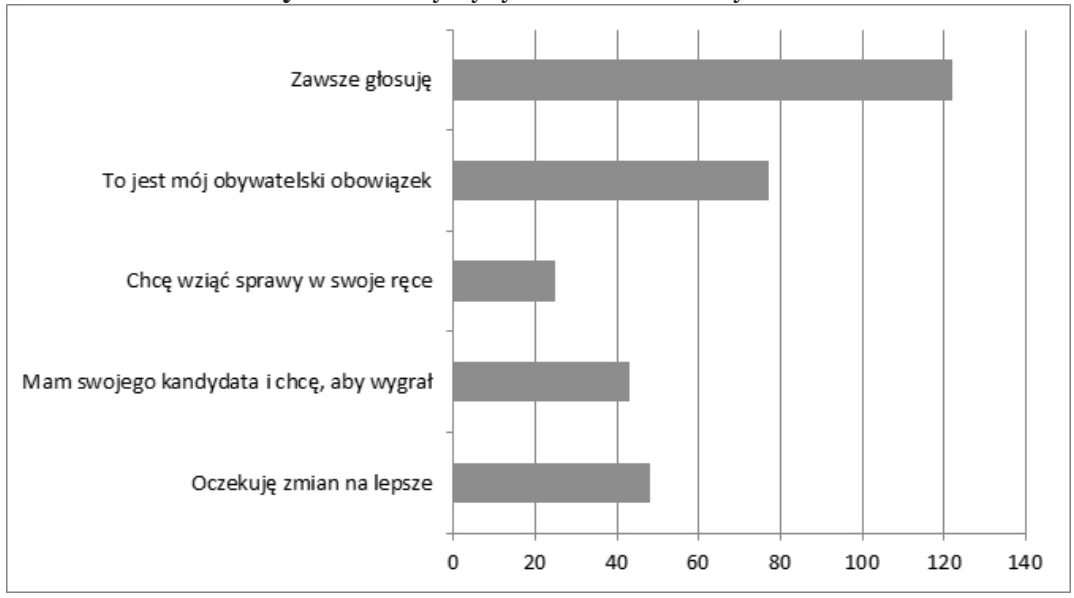

Źródło: opracowanie własne

Najczęściej wybieraną odpowiedzią w przypadku poziomu wykształcenia było regularne uczestnictwo w głosowaniu. Na drugim miejscu natomiast znalazło się poczucie obywatelskiego obowiązku. Różnica pojawiłasię dopiero w przypadku trzeciej z kolei odpowiedzi. Osoby $\mathrm{z}$ wykształceniem wyższym wskazywały na posiadanie konkretnego kandydata, którą to opcję wybrała tylko jedna osoba z wykształceniem pod- 


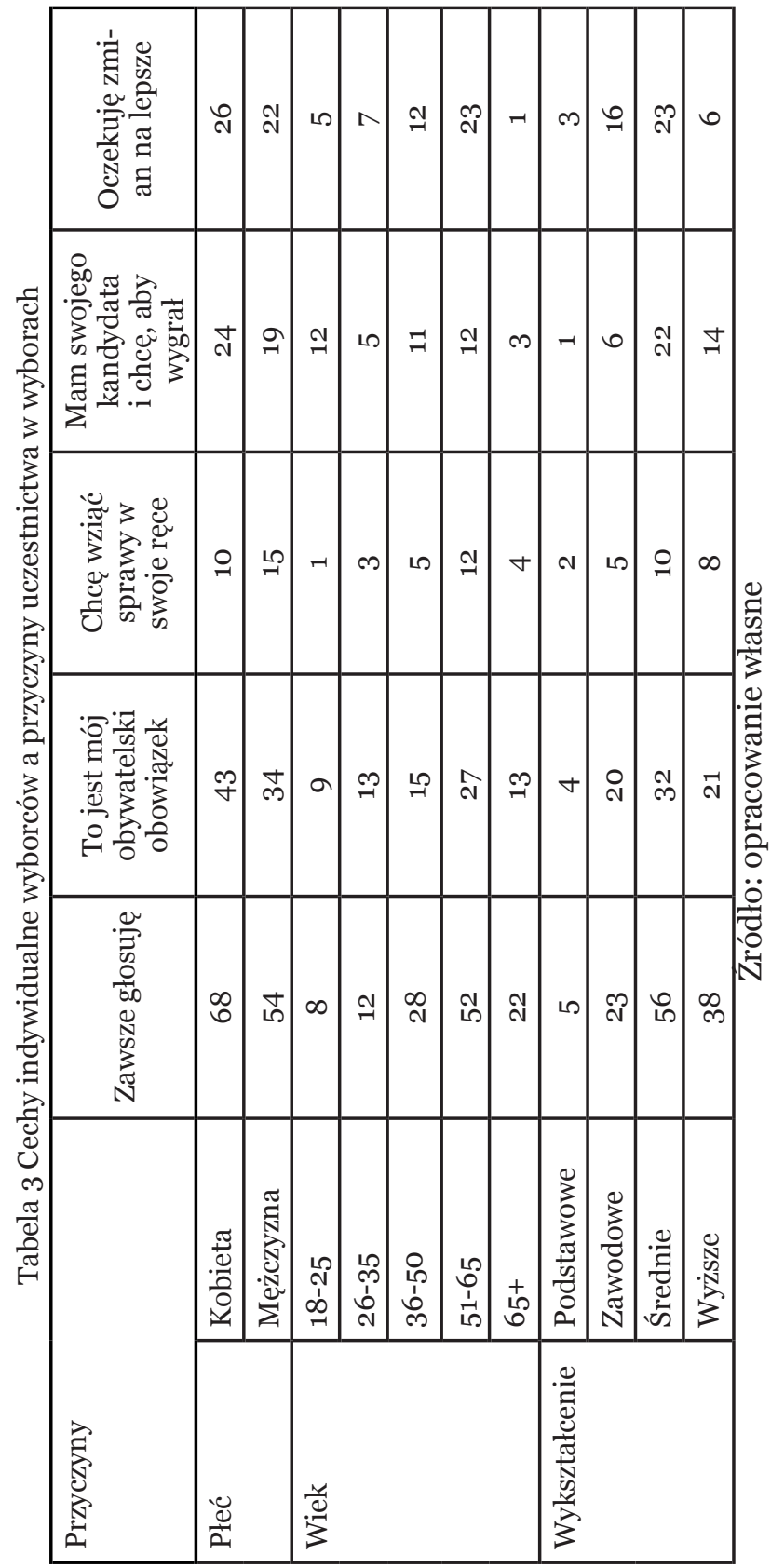


stawowym. Respondenci z pozostałych kategorii wybierali natomiast oczekiwanie zmian na lepsze, która to odpowiedź była najrzadziej wymienianą właśnie wśród osób z wykształceniem wyższym. Chęć wzięcia sprawy w swoje ręce była ostatnim z wybieranych powodów wśród respondentów z wykształceniem zawodowym i średnim. Rozkład deklarowanych przyczyn uczestnictwa w wyborach ze względu na indywidualne cechy wyborców obrazuje powyższa tabela.

\section{PREFERENCJE WYBORCZE}

RESPONDENTÓW, KTÓRZY ZADEKLAROWALI CHĘć UCZESTNICTWA W WYBORACH bądź nie byli jeszcze zdecydowani, proszono o wskazanie, na jakiego kandydata zamierzają oddać swój głos. Spośród 271 osób tylko 145 zdecydowało się na ujawnienie swojego wyboru ${ }^{5}$. Zdecydowaną przewagę wśród kandydatów startujących w wyborach w badaniach uzyskał Tomasz Ciszewicz (48\%), który sprawował ówcześnie funkcję burmistrza. $\mathrm{Na}$ drugim miejscu znalazł się Ryszard Bodziacki (27\%), następni w kolejności byli Amelia Szołtun (8\%), Andrzej Bycka (7\%) i Kazimiera Jakubowska (6\%). Najmniej wskazań uzyskał Leopold Owsiak (4\%). $\mathrm{Z}$ kolei, 126 respondentów postanowiło nie ujawniać swoich preferencji politycznych, z czego część stwierdzała, że nie podjęła jeszcze konkretnej decyzji, na kogo odda w dniu wyborów swój głos.

Wykres 3. Rozkład głosów na poszczególnych kandydatów (\%)

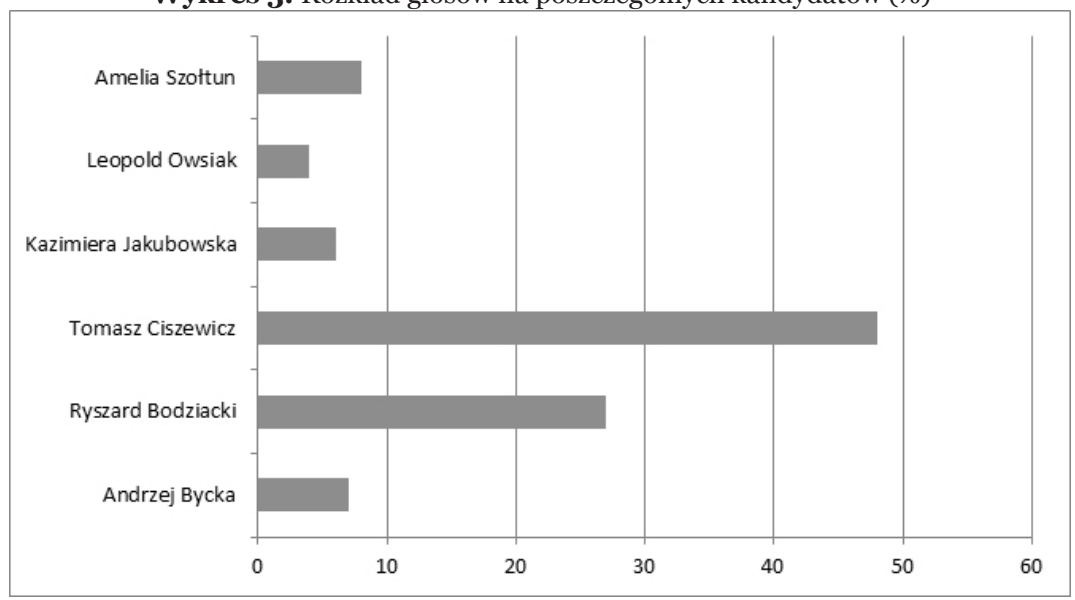

Źródło: opracowanie własne ${ }^{6}$

${ }^{5}$ Podział procentowy uwzględnia tylko respondentów, którzy zdecydowali się ujawnić swoje preferencje polityczne.

${ }^{6}$ Warto nadmienić, że kandydat, który w badaniach uzyskał najwięcej wskazań (To- 
W ankiecie znalazło się dziewięć przyczyn głosowania na poszczególnych kandydatów: (1) życiorys kandydata, (2) doświadczenie zawodowe, (3) cechy charakteru, (4) wygląd zewnętrzny, (5) program wyborczy, (6) etykieta partyjna, (7) poparcie znanych osób, (8) nośne hasło wyborcze, (9) ciekawa kampania wyborcza. Respondenci mogli wskazać więcej niż jedną odpowiedzi. Najczęściej ankietowani decydowali się na odpowiedź „doświadczenie zawodowe”. Wybrano ją 114 razy. Najrzadziej wskazywano na nośne hasło wyborcze. Zdecydowały się na to tylko 4 osoby. Częstotliwość wyboru poszczególnych przyczyn obrazuje poniższy wykres:

Wykres 4. Przyczyny głosowania na poszczególnych kandydatów

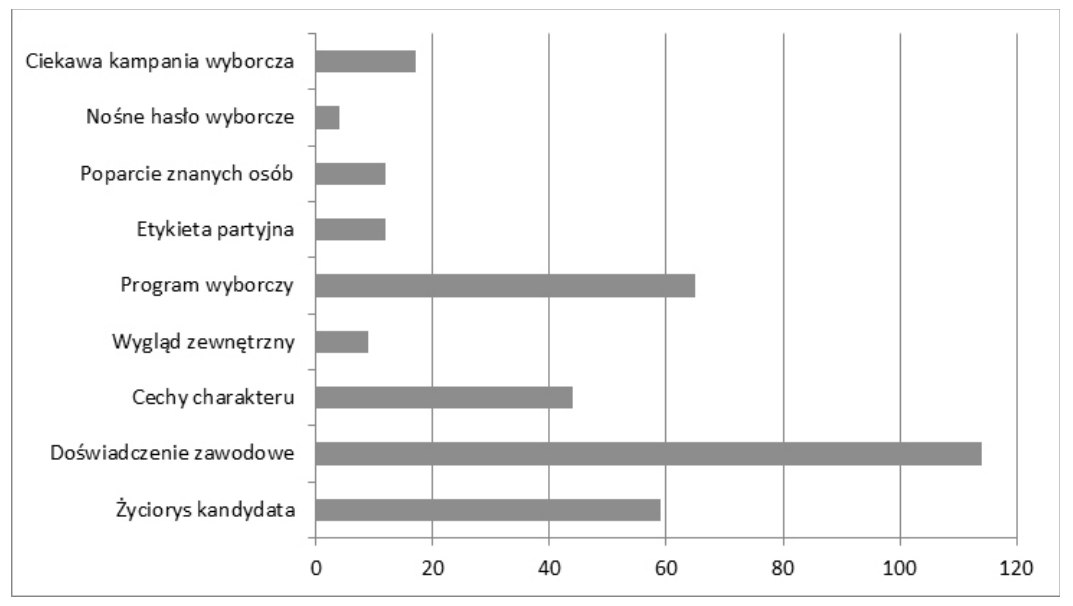

Źródło: opracowanie własne

Zarówno kobiety, jak i mężczyźni najczęściej wskazywali, że tym, co decyduje o oddaniu przez nich głosu na konkretnego kandydata, jest jego doświadczenie zawodowe. Szczegółowe dane znajdują się $\mathrm{w}$ tabeli numer 4 . W przypadku pozostałych odpowiedzi występują już różnice ze względu na płeć. Wśród kobiet drugim najczęściej wskazywanym elementem decydującym podczas głosowania jest program wyborczy, następnie cechy charakteru i życiorys kandydata. Mężczyźni wybierali najpierw życiorys kandydata, a dopiero na trzecim miejscu znalazł się program wyborczy z dużą

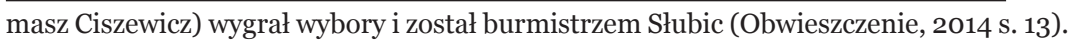


różnicą pomiędzy poszczególnymi motywacjami (życiorys kandydata - 35 mężczyzn, program wyborczy - 18 mężczyzn). Dla obu płci praktycznie nie ma znaczenia nośne hasło wyborcze kandydata, przy czym wśród kobiet równie rzadko padała odpowiedź „wygląd zewnętrzny”.

Uwzględniając wiek respondentów na poziomie najczęściej wymienianej odpowiedzi nastąpiła jednomyślność. W każdej kategorii wiekowej najwięcej ankietowanych wskazywało doświadczenie zawodowe. W grupie 36-50 lat ani razu nie pojawily się odpowiedzi „poparcie znanych osób” i „nośne hasło wyborcze”. Na ostatnią z tych przyczyn nie zdecydowała się również żadna osoba w wieku powyżej 65 lat, podobnie jak na ciekawą kampanię wyborczą. Wśród najmłodszych respondentów najmniej popularnym powodem głosowania na konkretnego kandydata był jego wygląd zewnętrzny. Zasadniczo jednak najrzadziej wybieraną odpowiedzią było „nośne hasło wyborcze”, którą wskazały tylko po jednej osobie z grupy 26-35 lat oraz 51-65 lat i dwie spośród najmłodszych respondentów.

W przypadku wykształcenia występują już różnice na poziomie najczęściej wybieranej odpowiedzi. Osoby, które ukończyły szkołę zawodową, średnią bądź studia wskazywały doświadczenie zawodowe kandydata. Respondenci z wykształceniem podstawowym decydowali się najczęściej na życiorys osoby startującej w wyborach, jednocześnie wśród tej grupy ankietowanych ani razu nie padły odpowiedzi: wygląd zewnętrzny, nośne hasło wyborcze czy ciekawa kampania wyborcza. W pozostałych kategoriach każda z przyczyn została wybrana co najmniej raz. W przypadku osób z wykształceniem średnim i wyższym najrzadziej decydowano się na nośne hasło wyborcze. Najmniej popularną odpowiedzią w grupie ankietowanych z wykształceniem zawodowym była natomiast „ciekawa kampania wyborcza”.

\section{TURA WYBORÓW}

OSTATNIĄ BADANĄ KWESTIĄ BYŁ SPOSÓB POSTĘPOWANIA W PRZYPADKU II tury wyborów. Na to pytanie odpowiadały osoby niezdecydowane bądź te, które zadeklarowały uczestnictwo w I turze. Respondenci musieli dokonać wyboru spośród sześciu możliwości: (1) nie zagłosuję, (2) poprę kandydata wskazanego przez mojego faworyta

${ }^{7}$ Dla mężczyzn „wygląd zewnętrzny” również nie miał dużego znaczenia (tylko 6 mężczyzn wybrało tą odpowiedź), przy czym uzyskał więcej wskazań niż „nośne hasło wyborcze” (1 wskazanie). Mniej wskazań niż „wygląd zewnętrzny” wśród mężczyzn uzyskało także „poparcie znanych osób” (5). 
z I tury, (3) poprę tego, który w I turze uzyskał lepszy wynik, (4) poprę tego, który w I turze uzyskał gorszy wynik, (5) zagłosuję przeciwko obecnie rządzącemu prezydentowi, jeśli ten wejdzie do II tury ${ }^{8}$, (6) podejmę niezależną decyzję. Ankietowani w tym przypadku mogli wskazać tylko jedną odpowiedź.

Respondenci najczęściej stwierdzali, że podejmą niezależną decyzję (43\%). Drugą najpopularniejszą opcją było głosowanie na kandydata wskazanego przez faworyta z I tury (25\%). Jednocześnie jednak 33 osoby stwierdziły, że jeśli doszłoby do II tury wyborów, nie wzięliby w niej udziału (16\%). Najrzadziej decydowano się na poparcie kandydata, który w I turze uzyskał gorszy wynik (3\%). Należy jednak zaznaczyć, że część respondentów miała problem ze zrozumieniem pytania i odmawiała udzielenia na nie odpowiedzi lub prosiła o dokładniejsze wyjaśnienie zagadnienia. Rozkład odpowiedzi na pytanie dotyczące postępowania w II turze wyborów obrazuje poniższy wykres nr 5 .

Wykres 5. Sposób postępowania w II turze (\%)

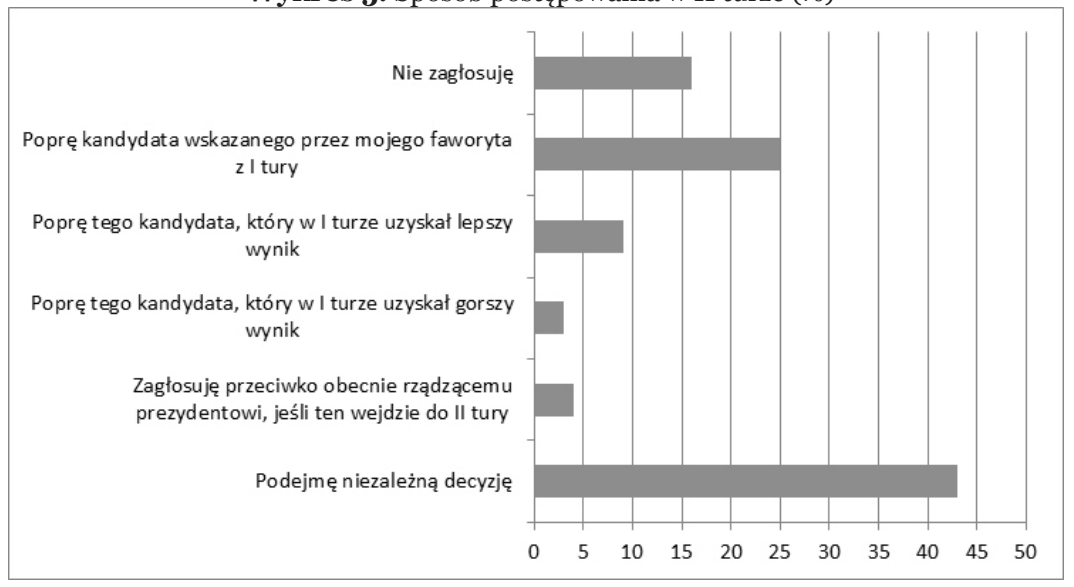

Źródło: opracowanie własne

${ }^{8}$ Ówcześnie stanowisko burmistrza w gminie Słubice sprawował Tomasz Ciszewicz. 


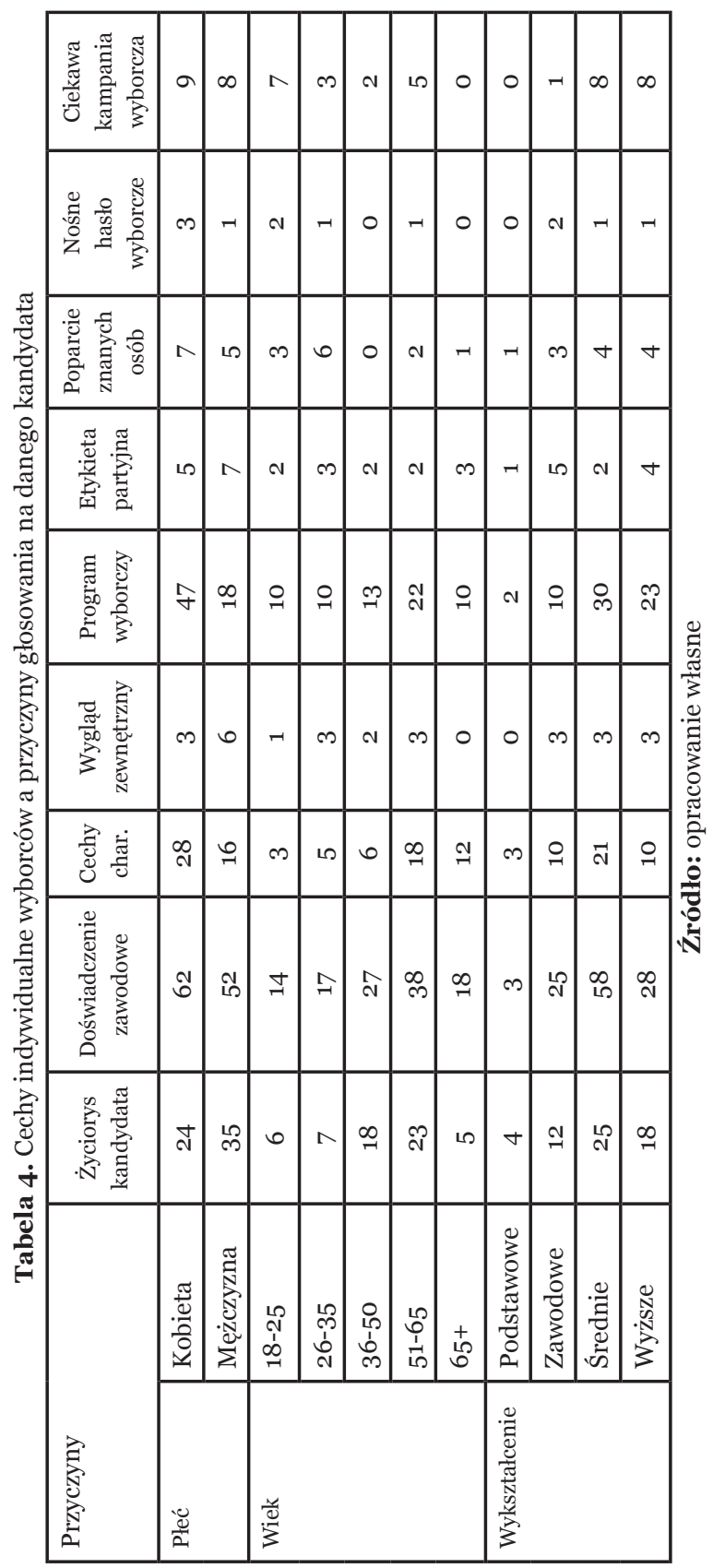


Bez względu na płeć, respondenci najczęściej decydowali, że w II turze podejmą niezależną decyzję podczas głosowania. Mężczyźni równie rzadko wybierali odpowiedź „zagłosuję przeciwko obecnie rządzącemu prezydentowi, jeśli ten wejdzie do II tury", jak i „poprę tego kandydata, który w I turze uzyskał gorszy wynik” (po 4 osoby). Ostatnia z opcji była również najmniej popularna wśród kobiet. Jeśli doszłoby do II tury głosowania nie uczestniczyłoby w nich spośród ankietowanych 18 kobiet i 15 mężczyzn.

W przypadku wieku, niezależnie od kategorii, najczęściej decydowano się na podjęcie niezależnej decyzji. Interesująco rozłożyły się pozostałe głosy w grupie 18-25 lat. Trzy odpowiedzi zostały wskazane sześciokrotnie - „nie zagłosuje”, „poprę kandydata, wskazanego przez mojego faworyta z pierwsze tury oraz poprę kandydata, który w pierwszej turze uzyskał lepszy wynik". Ani jedna osoba spośród najmłodszych respondentów nie zdecydowałaby się poprzeć kandydata z gorszym wynikiem w pierwszej turze. W kategorii wieku 65+ opcję „podejmę niezależną decyzję wybrano” więcej razy niż pozostałe wskazania zsumowane razem. W grupie 2635 lat nikt nie zdecydowałby się poprzeć kandydata z mniejszą liczbą głosów z poprzedniej tury i nie głosowałby negatywnie (przeciwko ówcześnie rządzącemu burmistrzowi).

W przypadku wykształcenia, również w każdej kategorii najczęściej wskazywano na podjęcie niezależnej decyzji. Wśród osób z wykształceniem podstawowym nikt nie zdecydowałby się na poparcie kandydata z gorszym wynikiem w I turze. Wśród osób z ukończonymi studiami najrzadziej padały odpowiedzi: „poprę tego kandydata, który w I turze uzyskał lepszy wynik”, „poprę tego kandydata, który w I turze uzyskał gorszy wynik” oraz „zagłosuję przeciwko obecnie rządzącemu prezydentowi, jeśli ten wejdzie do II tury”. Rozkład deklarowanych sposobów postępowania w II turze ze względu na indywidualne cechy wyborców obrazuje poniższa tabela. 


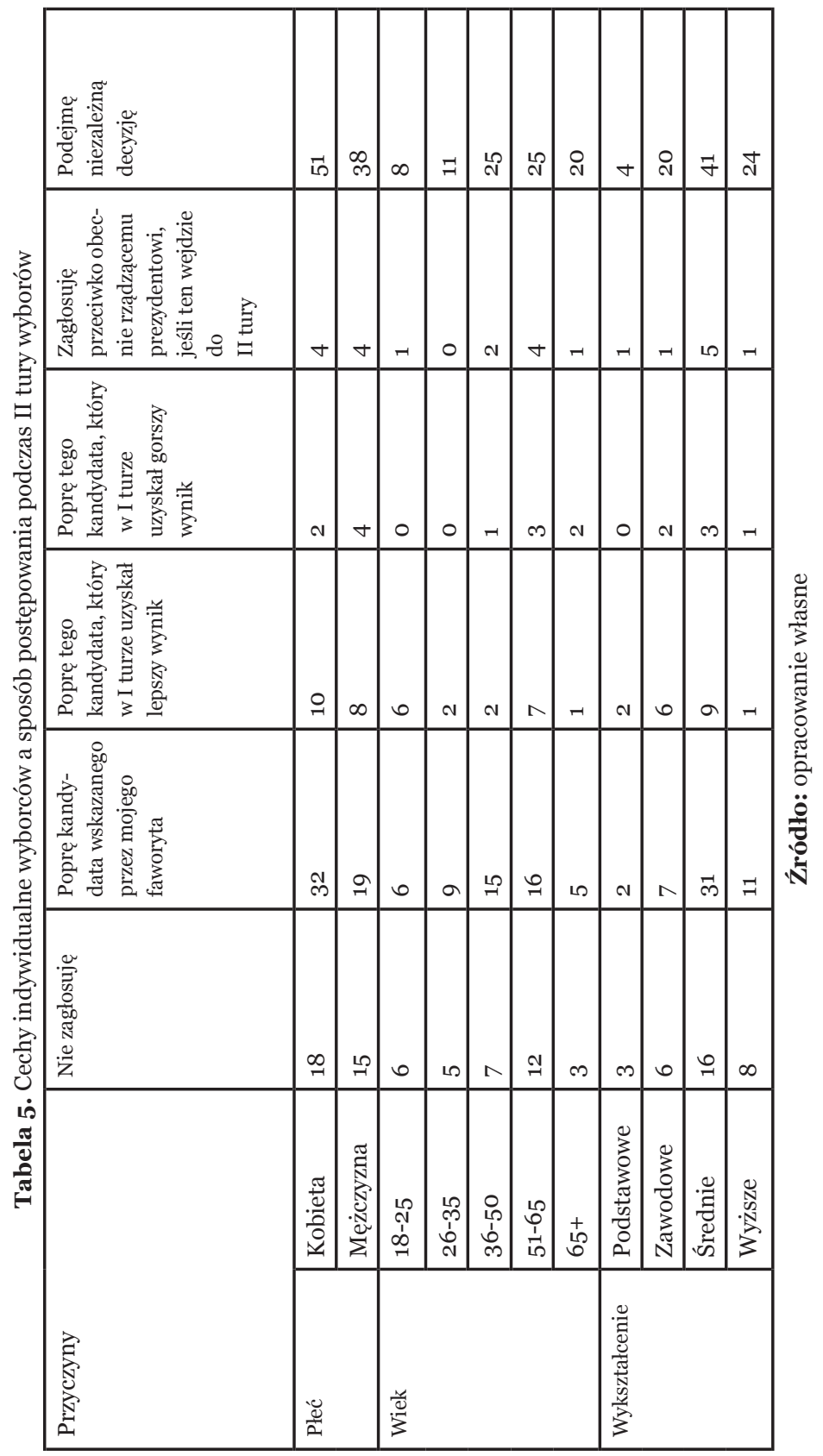




\section{Podsumowanie}

Według deklaracji respondentów większość zamierza uczestniczyć w wyborach samorządowych 6 listopada 2014 roku. Najbardziej popularną przyczyną było przyzwyczajenie. Respondenci motywowali swoje uczestnictwo w głosowaniu faktem, że zawsze w wyborach uczestniczą. Osoby, które zdecydowały się na absencje, argumentowały swoją decyzje rozczarowaniem zachowaniem polityków. Interesujące jest, że zarówno w przypadku motywacji uczestniczenia w wyborach, jak i absencji, najrzadziej wybierano odpowiedź, która wskazywałaby na siłę sprawczą respondentów (chcę wziąć sprawy w swoje ręce, nie chce brać na siebie odpowiedzialności), to zagadnienie wymaga jednak dalszych pogłębionych badań.

Okazało się, w przypadku preferencji wyborczych, że rzeczywiście istotniejsze są osobiste cechy kandydata (doświadczenie, życiorys) niż program wyborczy komitetu, który reprezentuje. Działania prowadzone w trakcie kampanii, niezależnie od jej jakości, według respondentów mają niewielkie znaczenie przy podejmowaniu przez nich decyzji wyborczej. W przypadku II tury osoby deklarowały, że podejmą niezależną decyzję i nie będą kierować się przy głosowaniu zewnętrznymi czynnikami (np. wynikiem kandydatów w I turze). Zgodnie z wynikiem badań można skonstatować, że na poziomie lokalnym mamy do czynienia ze zjawiskiem personalizacji polityki.

\section{Bibliografia}

Statystyczne Vademecum Samorządowca. Gmina miejsko-wiejska Stubice. Powiat Stubicki (2014), Urząd Statystyczny w Zielonej Górze.

Cybulska A. (2014), Wybory samorzq̨dowe, Komunikat z badań CBOS, Warszawa, nr 124/2014.

Obwieszczenie Komisarza Wyborczego w Zielonej Górze z dnia 22 listopada 2014 r. o wynikach wyborów wójtów, burmistrzów i prezydentów miast na obszarze województwa lubuskiego (2014), Komisarz Wyborczy w Zielonej Górze.

Piontek D. (2012), Personalizacja rywalizacji wyborczej $w$ kampanii parlamentarnej, Rocznik Nauk Społecznych", Tom 4, nr 3.

Ustawa z dnia 8 marca 1990 r. o samorządzie gminnym, Dz. U. 1990, nr 16, poz. 95 z późń. zm.

Ankiety z badań z Stubic. 


\section{SUMMARY}

THE ARTICLE PRESENTS THERESULTS OF RESEARCH CONDUCTEDIN THE municipality of Slubice. Their results clearly show that at the local level we have to deal with personalization local politics. The research also made it possible to estimate the turn ou tin this area, identify the reasons for absenteeism, an indication of the likely winners of the election for mayor and specify the reasons forvoting for a particular candidate. The project was implemented during the election campaign before the local elections of 2014 .

\section{Nota O AUTOCE}

Martyna Domańska [martyna.domanska@amu.edu.pl] - doktorantka w Zakładzie Badań Władzy Lokalnej i Samorządu Wydziału Nauk Politycznych i Dziennikarstwa Uniwersytetu im. Adama Mickiewicza w Poznań. Ukończyła studia na kierunku politologia, specjalność administracja samorządowa i administracja europejska. Zainteresowania naukowe koncentrują się na problematyce samorządu terytorialnego, w szczególności międzynarodowej współpracy samorządu regionalnego oraz wykorzystania funduszy europejskich przez polskie NGO. 